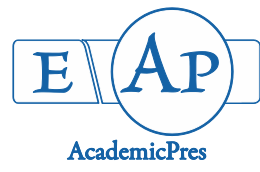

\title{
Nutrient Competition Mediated Antagonism of Microbes Against Rhizoctonia solani
}

\section{Manoj Kumar SOLANKI ${ }^{1}$, Sudheer KUMAR ${ }^{2}$, Mahesh S. YANDIGERI ${ }^{3 *}$, Rajesh Kumar SINGH ${ }^{1}$, Alok K. SRIVASTAVA ${ }^{1}$}

\author{
${ }^{1}$ ICAR-National Bureau of Agriculturally Important Microorganisms, Kusmaur, Mau, Uttar Pradesh -275101, \\ India;mkswings321@gmail.com; rajeshsingh999@gmail.com; aloksrivastva@gmail.com \\ ${ }^{2}$ ICAR-Indian Institute of Wheat \& Barley Research, Karnal-132001, India; Sudheer.Kumar@icar.gov.in \\ ${ }^{3}$ ICAR-National Bureau of Agricultural Insect Resources, P.B. No. 2491, H.A. Farm Post, Bellary Road, Bangalore-560032, Karnataka, \\ India; micromahesh@gmail.com( ${ }^{*}$ corresponding author)
}

\begin{abstract}
Plant growth-promoting (PGP) microorganisms are beneficial soil micro creatures which may facilitate plant growth by direct or indirect ways. Bacillus amyloliquefaciens MB101 (BA), Streptomyces atrovirens N23 (SA) and Hypocrea lixii NAIMCC-F-01760 (HL) were earlier reported to have the ability to manage the tomato root rot disease caused by Rhizoctonia solani $(R S)$ at some extent. In the present study, effect of nutrient supplementation like potato dextrose broth (PDB) and tomato root extract (TRE) on antagonism of these three microbes was characterized under the soil microcosm in order to understand the role of nutrient in microbe-microbe interaction. A moderate influence on the population of all three antagonists was resulted by PDB and TRE with $R S$. However, TRE and PDB were causing a significant impact on cell wall degrading enzymes and antifungal activity in the presence of $R S$. Moreover, hyphal degradation of $R S$ was proved by scanning electron micrographs in the absence of substrates. Nutrient competition enhanced the call wall degrading enzyme production. Therefore, the present study concluded the role of substrate in the mycoparasitism and also sustain the potential of the hereby methodology (soil microcosm) for screening of other soil-inhibiting organism in the future.
\end{abstract}

Keywords: antifungal activity; chitinase; glucanase; potato dextrose broth; tomato root extract

\section{Introduction}

Among soil-borne pathogens, Rbizoctonia solani is one of the economically important soil-inhabiting fungus that can survive saprophytically on dead organic matter in soil for a long time, either a resting structure 'sclerotia' or an actively growing mycelium (Solanki et al., 2011, 2014a; Patil and Solanki, 2016b). Biocontrol using antagonistic microbes has been considered as an alternative strategy to agrochemicals that are harmful to human health and environment. Numerous earlier reports describe the use of biocontrol agents (BCAs) such as Bacillus spp. (Solanki et al., 2012a, b), Trichoderma/Hypocrea spp. (Harman et al., 2004; Almeida et al., 2007; Solanki et al., 2011) and Streptomyces spp. (Boukaew et al., 2011; Malviya et al., 2014; Yandigeri et al., 2015). There are several mechanisms by plant growth promoting microbes (PGPM) that restrain disease incidence or severity, including antibiosis, antagonism for nutrients and space, as well as the production of fungal growth inhibitory molecules like cyanide and siderophores (Doornbos et al., 2012; Solanki et al., 2014b; Patil and Solanki, 2016a).

Utilization of microbial inoculates for protection of the root from infection of pathogens was targeted for eco-safe management of numerous crops, and rhizospheric microbes play a substantial role in the management of plant pathogens (Bais et al., 2006; Compant et al., 2010; Patil and Solanki, 2016a). All microbes (bacteria and fungi) found in nature associated with the root and rhizhosphere have diverse ability to utilize (catabolise) all naturally occurring compounds as their sources of carbon for energy production (Yu et al., 2002; Hartmann et al., 2009; Malviya et al., 2014; Finkel et al., 2017). In comparison to bulk soil, the rhizosphere is rich in nutrients because of rhizodeposition (Bais et al., 2004). Rhizodeposits consist of the total carbon transferred from the plant root to the soil During the hostmicrobes interaction plants root plays key role by releasing 
carbon-containing metabolites, proteins, phenols, organic acids and amino acids into the soil matrix (Bais et al., 2006; Arora et al., 2008).

A wide variety of plant beneficial microbes act as mycoparasites and produce a number of cell wall degrading enzymes (CWDEs), including cellulases, chitinases, glucanases and proteases, which helps them to extract nutrients from others fungal pathogens (Cao et al., 2008; Huang et al., 2016). In our previous studies, it was found that CWDEs such as chitinases and $\beta$-1, 3-glucanases have been playing a prominent role in mycoparasitic interaction and management of $R$. solani by Bacillus spp. and Trichoderma spp. in tomato plants (Solanki et al., 2011, 2012b).

In the present study, attempts were made to identify the role of artificial (potato dextrose broth) and natural (tomato root extract) substrates during the interaction of antagonist and plant pathogen. Therefore, three microbes, Bacillus amyloliquefaciens, Streptomyces atrovirens and Hypocrea lixii were evaluated against tomato root rot, causing pathogen $R$. solani, under an artificial soil microcosm, and antagonist population, antifungal activity and cell wall degrading enzymes (CWDEs) were estimated in the presence and absence of $R$. solani.

\section{Materials and Methods}

\section{Microorganisms and antagonism assay}

Active strains of Rhizoctonia solani (RS), Bacillus amyloliquefaciens MB101 (BA), Streptomyces atrovirens N23 $(S A)$ and Hypocrea lixii NAIMCC-F-01760 (HL) were obtained from National Agriculturally Important Microbial Culture Collection (NAIMCC), National Bureau of Agriculturally Important Microorganisms (NBAIM), Mau, Uttar Pradesh, India and all strains were maintained as guideline of NAIMCC. In-vitro antagonistic activity of all three microbes ( $B A, S A$ and $H L$ ) was performed against $R S$ by dual culture assay according to the procedure of Arora $e t$ al. (2008) and Morton and Stroube (1955). Each experiment performed in triplicates and pooled data were used for analysis.

\section{Root exudates preparation}

Seeds of Lycopersicon esculentum Mill. cv. 'Novratan' were the surface sterilized with ethanol $(70 \% \mathrm{v} / \mathrm{v})$ for $5 \mathrm{~min}$, followed by sodium hypochlorite (1\%) for $1 \mathrm{~min}$ and rinsed thrice with sterile distilled water, and germinated in autoclaved $\left(20 \mathrm{~min} ; 121^{\circ} \mathrm{C}\right)$ perlite. After germination, plantlets were transferred in a steam sterilized $(20 \mathrm{~min}$; $121{ }^{\circ} \mathrm{C}$ ) mixture of silicate sand, expanded clay and soil $(1: 1: 1 ; \mathrm{v} / \mathrm{v})$. Plants were grown in a growth chamber (day/night cycle: $16 \mathrm{~h} ; 23^{\circ} \mathrm{C} / 8 \mathrm{~h} ; 19^{\circ} \mathrm{C}$; relative humidity $50 \%$ ) for five weeks; the root system of each tomato plant was washed under tap water and incubated in Erlenmeyer flasks filled with $100 \mathrm{~mL}$ sterilized Milli-Q water for $22 \mathrm{~h}$. Solutions were sterilized by filtration through Whatman No. 4 and No. 42 filter papers and then $\varnothing 0.22 \mathrm{~mm}$ nitrocellulose filters (Millipore) and lyophilized. Concentrations were adjusted to a ratio of $1 \mathrm{~g}$ of the root fresh weight equivalent to $10 \mathrm{~mL}$ of exudates solution with sterilized Milli-Q water. The $\mathrm{pH}$ was then adjusted to 6.0 before being sterilized again by filtration through $\varnothing 0.22$ $\mathrm{mm}$ nitrocellulose filters and lyophilised solution was kept at $-20^{\circ} \mathrm{C}$ until use.

\section{Pathogen biomass preparation}

The inoculum of $R S$ was prepared in Erlenmeyer flasks $(250 \mathrm{~mL})$ containing pearl millet seeds $(80 \mathrm{~g})$, bean meal $(20 \mathrm{~g})$ and distilled water $(30 \mathrm{~mL})$ autoclaved for two consecutive days for $1 \mathrm{~h}$ at $121^{\circ} \mathrm{C}$. Three disks of $R$. solani ( 5 days old) were transferred into each flask and incubated at $28 \pm 2{ }^{\circ} \mathrm{C}$ for 3 weeks and grown biomass $\left(\sim 10 \mathrm{~g} \mathrm{~kg}^{-1}\right)$ was mixed thoroughly in autoclaved soil to prepare pathogen infested microcosm and non-infested microcosm also infested with the same amount of autoclaved mycelial biomass.

\section{Microbial inoculums preparation}

The suspension of $B A$ was prepared by inoculating 0.1 $\mathrm{mL}$ of actively growing culture in $250 \mathrm{~mL}$ of nutrient broth (NB, HiMedia, India) and incubated on a rotary shaker $(120 \mathrm{rpm})$ at $28 \pm 2{ }^{\circ} \mathrm{C}$ for $24 \mathrm{~h}$. Bacterial cells were harvested by centrifugation $8,000 \times g$ for $10 \mathrm{~min}$ (Sigma $3 \mathrm{~K} 30$ centrifuge, Germany), resuspended and diluted in sterile distilled water up to $\sim 10^{7}$ cells $\mathrm{mL}^{-1}$. For $S A$, a loopful culture was inoculated in ISP2 broth $(250 \mathrm{~mL})$ and incubated for ten days, at $32 \pm 2{ }^{\circ} \mathrm{C}$ at $150 \mathrm{rpm}$. The cell suspension was centrifuged at $8,000 \times g$ and the pellet was washed with sterile distilled water and cell concentration maintained at $\sim 10^{7}$ cells $\mathrm{mL}^{-1}$. HL was multiplied in a broth containing molasses $(100 \mathrm{~mL}), \mathrm{KH}_{2} \mathrm{PO}_{4}(2 \mathrm{~g})$, $\mathrm{MgSO}_{4} .7 \mathrm{H}_{2} \mathrm{O}(0.2 \mathrm{~g})$, sucrose $(10 \mathrm{~g})$ and distilled water (1L) $(\mathrm{pH} 5.8)$. After 10 days incubation, conidia were separated from mycelia by filtering though sterile glass wool and quantified by a haemocytometer. The conidial count was adjusted to $\sim 10^{7}$ conidia $\mathrm{mL}^{-1}$ and these microbial suspensions were used for the soil microcosm experiment.

\section{Soil microcosm study}

Rhizospheric soil with the following characters: sand $64 \%$; silt $29.2 \%$; clay $23.4 \%$; bulk density $49.3 \mathrm{~g} / \mathrm{cm}^{3}$; water holding capacity 67.42\%; $\mathrm{pH} 6.25 ; \mathrm{EC}_{\mathrm{e}} 1.52 \mathrm{dS} \mathrm{m}^{-1}$, was used in the study. Soils were freshly collected prior to the experiments and mixed thoroughly, sieved to $2 \mathrm{~mm}$ particle size and sterilized by three time's consecutive autoclaving $\left(121^{\circ} \mathrm{C}\right.$ for $\left.1 \mathrm{~h}\right)$. Two types of experiment were performed in soil microcosm (2L glass beaker). First $R S$ infested (with pathogen) and second non-infested (without pathogen) microcosm and both microcosms were treated with $5 \mathrm{~mL}$ of microbial suspensions: $B A\left(\sim 10^{7}\right.$ cells $\left.\mathrm{mL}^{-1}\right), S A\left(\sim 10^{7}\right.$ cells $\left.\mathrm{mL}^{-1}\right)$ and $H L\left(\sim 10^{7}\right.$ spores $\left.\mathrm{mL}^{-1}\right)$ by pipetting. Then, all inoculated microcosms were supplemented every alternate day with PDB and TRE at a rate of $0.1 \mathrm{~mL} \mathrm{~g}^{-1}$ soil up to 21 days. Each supplement was applied with sterilize distilled water in a soluble form, and only distilled water used as control. After microbes and substrate addition, the whole bulk of soil in the microcosm was thoroughly mixed and all microcosms were covered with sterilized tin foil and transferred to a growth chamber $\left(19^{\circ} \mathrm{C}\right.$ night and $26^{\circ} \mathrm{C}$ day, relative humidity $65 \%$ ) for 21 days, regularly checked 
394

and adjusted to $40 \%$ of soil water holding capacity (WHC) with sterile distilled water. The microcosms were stirred every day and when correction of the moisture content was necessary. The experiment was performed with three individual replicates. After 21 days, soil samples were collected from each soil microcosm and analysis performed.

\section{Population monitoring in microcosm}

To monitor the population of the introduced biocontrol agents in the soil after 3 weeks ( 21 days), $10 \mathrm{~g}$ of soil from each microcosm was taken and assessed by dilution plating method. Different agar media were used for isolation and enumeration of $B A, S A$ and $H L$, respectively. The population of $B A$ was enumerated on trypticase soy medium ( $\mathrm{g} \mathrm{L}^{-1}$ : pancreatic digest of casein 15.0; papaic digest of soybean 5.0; sodium chloride 5.0; $\mathrm{pH} 7.3$ ) and $S A$ on ISP2 medium ( $\mathrm{g} \mathrm{L}^{-1}$ : yeast extract 4.0; malt extract 10.0; glucose 4.0; $\mathrm{pH} 7.3$ ) supplemented with an antifungal antibiotics nystatin $\left(25 \mu \mathrm{g} \mathrm{mL}^{-1}\right)$ and actidione $\left(50 \mu \mathrm{g} \mathrm{mL}^{-1}\right)$. Fungal culture $H L$ was enumerated using potato dextrose agar (HiMedia, India) supplemented with antibacterial antibiotics streptomycin $\left(50 \mu \mathrm{g} \mathrm{mL}^{-1}\right)$ and chloramphenicol $\left(25 \mu \mathrm{g} \mathrm{mL}^{-1}\right)$. The identities of the cultures were confirmed by the compound microscopy on the basis of microscopic characteristics. The morphological characteristic of SA was confirmed based on sand yellow substrate and grey aerial mycelial colour on ISP2 medium. $B A$ culture was identified on the basis of a rod shaped cells in microscopy studies and Gram positive reaction. Identity of $H L$ was established on the basis of mycelia growth conidia and conidiophores morphology and mycelial growth and $R S$ on the basis of septate mycelium.

\section{Soil extract extraction}

Soil extract was extracted after 21 days incubation by vigorously shaking of the microcosm soil of all treatments at a ratio of $1: 2(\mathrm{w} / \mathrm{v})$ for $30 \mathrm{~min}$ in sterile phosphate buffer $\left(\mathrm{NaCl}-80.0 \mathrm{~g}, \mathrm{KCl}-2.0 \mathrm{~g}, \mathrm{Na}_{2} \mathrm{HPO}_{4}-11.5 \mathrm{~g}, \mathrm{KH}_{2} \mathrm{PO}_{4}-2.0 \mathrm{~g}\right.$, $\mathrm{H}_{2} \mathrm{O}-1 \mathrm{l}$ and $\left.\mathrm{pH}-7.2\right)$. An aliquot of the mixture $(250 \mathrm{~mL})$ was transferred to a sterile centrifuge tube and centrifuged at $1000 \times \mathrm{g}$ for $10 \mathrm{~min}$ to remove large particles, then at 3,000 $\times \mathrm{g}$ for $10 \mathrm{~min}$ to obtain the active supernatant and then sterilized by filtration through $\varnothing 0.22 \mathrm{~mm}$ nitrocellulose filters and solutions were kept in $-20^{\circ} \mathrm{C}$ until use.

\section{Poisoned food technique and hydrolytic enzyme estimation}

Mycelial growth inhibition was evaluated by the poisoned food technique (Luo et al., 2005). PDA and PDB media were amended with aqueous soil extract (10 and $20 \%$ ) and active $R$. solani mycelia discs inoculated on the PDA plate in center and in $100 \mathrm{~mL}$ potato dextrose broth and incubate at $28 \pm 2{ }^{\circ} \mathrm{C}$ for 5 days. Moreover, CWDEs of soil extract also determined, chitinase (EC 3.2.1.14) activity of the extract was determined using the modified method of Trotta et al. (1996) and $\beta-1,3$ Glucanase was assayed by a modified method using laminarin as substrate according to Lethbridge et al. (1978). Soil chitinase (EC 3.2.1.14) activity was assessed by measuring the amount of the reducing end group, N-acetyl glucosamine (NAG), produced from colloidal chitin (Wen et al., 2002). Soil extract $(1 \mathrm{~mL})$ was mixed with $0.25 \mathrm{~mL}$ of toluene, $4 \mathrm{~mL}$ of $50 \mathrm{mM} \mathrm{NaOAc}$ buffer ( $\mathrm{pH} 5.0$ ) and $1 \mathrm{~mL}$ of $0.5 \%$ colloidal chitin in a test tube and kept at $37^{\circ} \mathrm{C}$ for 2 hours. After this period, $1 \mathrm{~mL} 0.5 \mathrm{M}$ of $\mathrm{CaCl}_{2}$ and $4 \mathrm{~mL}$ of $0.5 \mathrm{M} \mathrm{NaOH}$ were added and mixed thoroughly. The mixture was centrifuged at $1,000 \mathrm{~g}$ for $20 \mathrm{~min}$ to yield a soil-free supernatant then filtered through Whatman No. 2 filter paper. A $1.0 \mathrm{~mL}$ quantity of Schales' reagent $(0.5 \mathrm{M}$ sodium carbonate and $1.5 \mathrm{mM}$ potassium ferricyanide) was added to $0.75 \mathrm{~mL}$ of the filtrate, and then the reaction was stopped by heating in boiling water for $15 \mathrm{~min}$. Chitinase activity was calculated by measuring NAG concentration at 420 $\mathrm{nm}$, in conjunction with data from a NAG standard curve. One unit of chitinase activity was defined as the amount of enzyme that liberated $1 \mu \mathrm{g}$ of NAG g-1 $\mathrm{h}^{-1}$ at $37^{\circ} \mathrm{C}$. Enzyme analysis was performed three replicates and all the data collected were pooled for statistical analysis. The $\beta-1,3$ Glucanase was assayed using laminarin as substrate (Lethbridge et al., 1978). The reaction mixture for laminarin contained $2 \mathrm{~mL}$ soil extract, $0.2 \mathrm{~mL}$ of $0.1 \mathrm{M}$ citrate buffer $(\mathrm{pH} 4.6)$ and $1.6 \mathrm{mg}$ soluble laminarin. The reaction mixture was incubated at $37^{\circ} \mathrm{C}$ for $1 \mathrm{~h}$ with gentle agitation, and then was stopped in both tests by boiling for 20-30 min. The citrate buffer was prepared by dissolving separately $2.1 \mathrm{~g}$ of citric acid monohydrate in $100 \mathrm{~mL}$ distilled water and $2.941 \mathrm{~g}$ tri-sodium citrate dihydrate in an-other $100 \mathrm{~mL}$ distilled water, then $44.5 \mathrm{~mL}$ of the first were mixed with $55.5 \mathrm{~mL}$ of the second. One millilitre of the sample was added at $4{ }^{\circ} \mathrm{C}$ to $5 \mathrm{~mL}$ anthrone reagent, the sample-reagent mixture was immediately boiled for $10 \mathrm{~min}$, and then the samples were kept in the dark at $4{ }^{\circ} \mathrm{C}$ for $20-30$ min for colour development. Then, the absorbance of the reactant mixtures was measured at $620 \mathrm{~nm}$ by spectrophotometer. This enzyme analysis was performed using three replicates and all the data collected were pooled for statistical analysis. All experiments were performed with three individual replicates and data pooled before analysis.

\section{Scanning electron microscopy}

The samples of test fungi $R S$ collected by sterile needle from all microcosms $(B A, S A$ and $H L)$ with or without substrates and all samples were evaluated by scanning electron microscopy (SEM). The visual hyphae of $R S$ was taken after 21 days and fixed for $46 \mathrm{~h}$ in $2 \%(\mathrm{v} / \mathrm{v})$ glutaraldehyde in $0.2 \mathrm{M}$ phosphate buffer ( $\mathrm{pH}$ 6.8) at room temperature. Samples were rinsed thoroughly for $1-2 \mathrm{~h}$ with $0.2 \mathrm{M}$ phosphate buffer ( $\mathrm{pH} 6.8$ ) and then dehydrated in a graded acetone series (30, 50, 70, 80, 90 and $100 \%)$, each grade for $30 \mathrm{~min}$ and three times for $100 \%$ acetone. Fully dehydrated samples were dried in a critical point dryer (HCP-2, Hitachi), mounted on stubs and then coated with gold (200 nm thickness) in a sputter coater (JFC-1600, JEOL). The coated specimens were examined with an SEM (JSM63804, JEOL Ltd) at $10 \mathrm{kV}$.

\section{Statistical analysis}

Data were analyzed with the SPSS program version 16.0 by analysis of variance (ANOVA) and significant differences among treatments and control groups were determined by Duncan's Multiple Range Test (DMRT) $(P \leq 0.05)$. 


\section{Results}

Effect of nutrient supplementation on microbial
propagation

In the dual culture assay, all three antagonistic isolates inhibited the growth of $R S$ up to $55 \%$ on PDA medium. On the basis of in-vitro antagonism, these isolates were selected for the microcosm study. The effect of potato dextrose broth and tomato root exudates (TRE) on microbial population was studied in soil microcosm and the results were represented in Fig. 1. In the soil microcosm study $B A$ alone showed less growth with $R S$ and a maximum population of $B A$ resulted with PDB treated microcosm without pathogen (Fig. 1a). However, it was slightly reduced in the treatment $B A+R S+\mathrm{PDB}$. But in the presence of $R S+\mathrm{TRE}, B A$ population was enhanced significantly as compared to the TRE alone (Fig. 1a). In the next, maximum population of $S A$ resulted with $R S+\mathrm{PDB}$, and was followed by PDB, $R S, R S+\mathrm{TRE}$ and TRE. However, $S A$ alone showed less population as compared to other treatments like with $R S$, PDA and TRE (Fig. 1b). Moreover, similar kind of growth pattern also resulted in the case of $H L$ with $R S+\mathrm{PDB}$ treated microcosm, followed by $H L+R S+\mathrm{TRE}$, but the rest of the treatments showed non-significant changes in $H L$ population (Fig. 1c).

\section{Effect of nutrient supplementation on antifungal activity} and $C W D E s$

Microbial soil microcosm study was performed to evaluate the effect of PDB and TRE on antagonism of three antagonistic microbes. Results in Table 1 had shown that antifungal activity of soil extract influenced by the substrate supplementation and the presence of the $R S . B A$ alone and with $R S$ showed maximum inhibition of $R S$ growth and minimum inhibition resulted with extract of $B A+R S+\mathrm{PDB}$ at $10 \%$ concentration (Table 1 ). Likewise, $S A$ alone showed more effect on mycelia growth, but $S A+R S+\mathrm{PDB}$ reduced the antifungal activity and $S A+R S$ inhibited the growth up to $78 \%$ on PDA plates, while minimum mycelia dry wt. $0.21 \mathrm{~g}$ resulted (Table 1). Similarly, $H L+R S$ showed maximum antifungal activity up to $75 \%$ (Table 1 ). After invitro antifungal activity, quantification of CWDEs was performed and chitinase and $\beta$-1, 3-glucanase enzyme resulted significantly higher with $R S$ as compared to without $R S$, whereas it also significantly reduced by PDB and TRE supplementation as compared to only water. Maximum chitinase accumulation accrued with $B A+R S$ and it was significantly different as compared to the $S A+R S$ and $H L+R S$ in the presence of water (Fig. 2a), and similar trend also followed by $H L+R S$. Likewise, $\beta$-1, 3-glucanase also resulted higher with soil extract of $B A+R S$ treated microcosm without the nutrient supplements and it was significantly different as compared to control (Fig. 2b).

\section{Scanning electron microscopy}

After study of CWDE's and antifungal activity, the mycoparasitic behaviour of all antagonists conformed by SEM. Fig. 3a showed healthy mycelia of $R S$ and damaged mycelia of $R S$ by antagonist $B A$ recovered from $B A+R S$ treated microcosm without supplementation, and rod shaped colony of $B A$ were attached on the damaged $R S$ mycelia (Fig. 3b). Likewise, mycelia of $R S$ clearly inhibited in the $S A+R S$ treated microcosm in the absence of the nutrient (Fig. 3c); under microscope deformation and increased branching on the $R S$ mycelia was observed (Fig. 3c). Likewise, microscopic observation of the $H L+R S$ microcosm showed that the mycoparasitism of $H L$ hyphae on $R S$ mycelia induced in the absence of nutrient (Fig. 3d) and deformation of $R S$ mycelia by coiling were clearly detected.
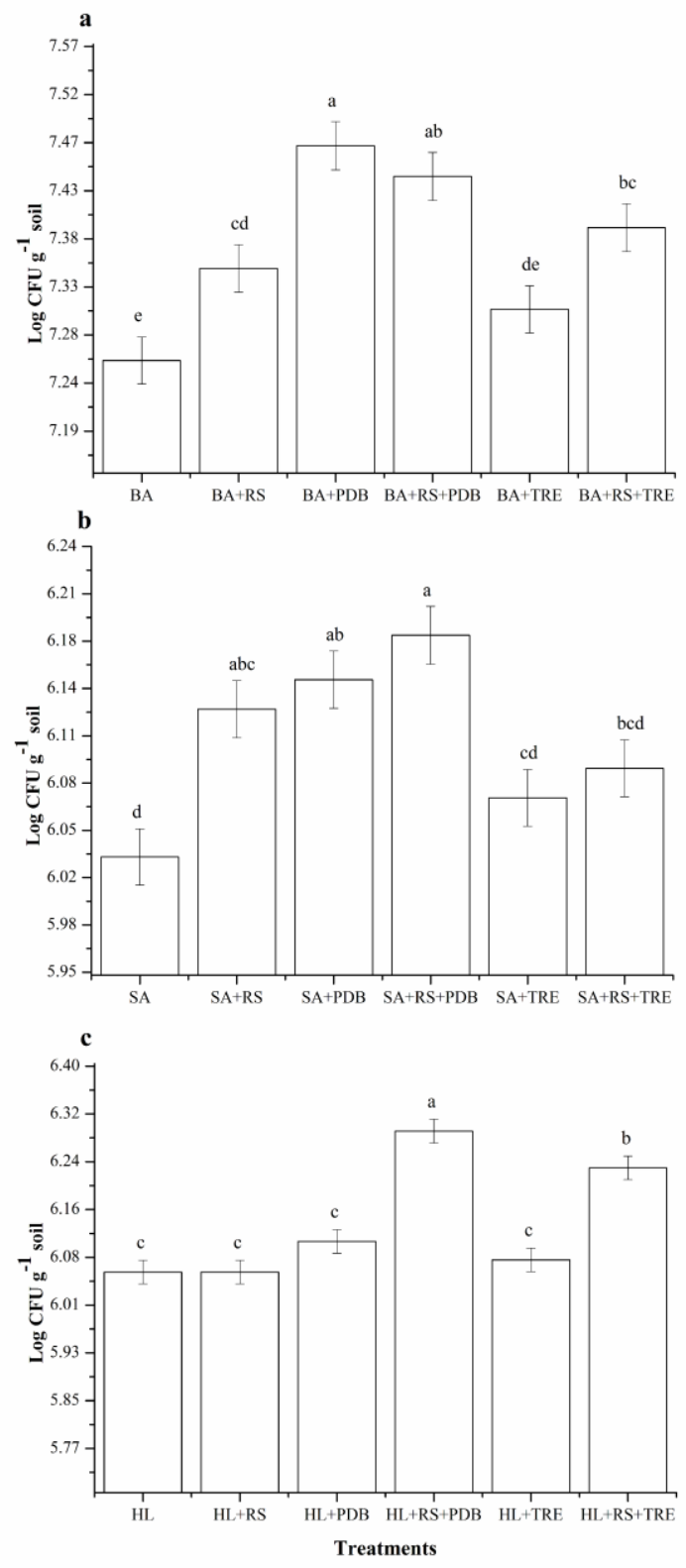

Fig. 1. Effect of nutrient supplements (potato dextrose brothPDB and tomato root extract-TRE) on populations of antagonist with or without pathogen: a - Bacillus amyloliquefaciens $\mathrm{MB} 101(B A) ; \mathbf{b}$ - Streptomyces atrovirens N23 (SA); c - Hypocrea lixii NAIMCC-F-01760 (HL), the vertical bars indicate the standard error of three replications ( $\mathrm{n}$ $=3$ ) and different letters on the error bars indicate significant difference $(P \leq 0.05)$ analyzed by Duncan's Multiple Range Test (DMRT) 
396

Table 1. Effect of soil extract (extracted from microcosm treated with different substrate and antagonistic microbes) on the growth of Rhizoctonia solani by poison food method

\begin{tabular}{|c|c|c|c|c|c|c|c|c|c|}
\hline \multirow{2}{*}{$\frac{\text { Treatments }}{\text { Conce }}$} & \multirow{2}{*}{$\begin{array}{l}\text { Supplementation } \\
\text { ations }(\mathrm{v} / \mathrm{v})\end{array}$} & \multicolumn{2}{|c|}{ Growth in $\mathrm{mm}(\mathrm{cm})$} & \multicolumn{2}{|c|}{ \% Inhibition } & \multicolumn{2}{|c|}{ Mycelia dry wt (g) } & \multicolumn{2}{|c|}{ \% Inhibition } \\
\hline & & $10 \%$ & $20 \%$ & $10 \%$ & $20 \%$ & $10 \%$ & $20 \%$ & $10 \%$ & $20 \%$ \\
\hline \multirow{3}{*}{ BA } & alone & $2.97 \mathrm{~h}$ & $2.26 \mathrm{~g}$ & $66.96 \mathrm{e}$ & $74.89 \mathrm{f}$ & $0.41 \mathrm{~g}$ & $0.30 \mathrm{gh}$ & $46.74 \mathrm{i}$ & $65.57 \mathrm{f}$ \\
\hline & PDB & $3.96 \mathrm{e}$ & $3.27 \mathrm{~d}$ & $55.96 \mathrm{~h}$ & $63.67 \mathrm{i}$ & $0.45 \mathrm{e}$ & $0.44 b$ & $41.26 \mathrm{j}$ & 49.201 \\
\hline & TRE & $3.76 f$ & $3.07 \mathrm{ef}$ & $58.19 \mathrm{~g}$ & $65.89 \mathrm{gh}$ & $0.44 \mathrm{ef}$ & $0.42 \mathrm{c}$ & $45.50 \mathrm{i}$ & $51.56 \mathrm{k}$ \\
\hline \multirow{3}{*}{$\mathrm{BA}+\mathrm{RS}$} & alone & $1.83 \mathrm{kl}$ & $1.11 \mathrm{k}$ & $79.63 \mathrm{ab}$ & $87.67 \mathrm{~b}$ & 0.271 & $0.19 \mathrm{~m}$ & $63.20 \mathrm{~cd}$ & $78.48 \mathrm{a}$ \\
\hline & PDB & $1.99 \mathrm{jk}$ & $1.78 \mathrm{~h}$ & $77.89 b c$ & 80.19 e & $0.35 \mathrm{i}$ & $0.23 j$ & $51.36 \mathrm{~h}$ & $73.50 \mathrm{~d}$ \\
\hline & TRE & $1.97 \mathrm{jk}$ & $1.49 \mathrm{i}$ & $78.11 b c$ & $83.48 \mathrm{~d}$ & $0.33 \mathrm{j}$ & $0.201 \mathrm{~m}$ & $59.46 \mathrm{e}$ & $76.95 \mathrm{ab}$ \\
\hline \multirow{3}{*}{ SA } & alone & $3.66 f$ & $3.02 \mathrm{f}$ & $59.30 \mathrm{~g}$ & $66.41 \mathrm{~g}$ & $0.36 \mathrm{i}$ & $0.31 \mathrm{fg}$ & $55.03 \mathrm{fg}$ & $64.57 \mathrm{fg}$ \\
\hline & PDB & $4.95 \mathrm{~b}$ & $3.76 \mathrm{c}$ & $44.96 \mathrm{k}$ & $58.19 j$ & $0.49 \mathrm{~d}$ & $0.40 \mathrm{~d}$ & $38.71 \mathrm{j}$ & $54.47 \mathrm{j}$ \\
\hline & TRE & $4.75 c$ & $3.17 \mathrm{de}$ & $47.19 \mathrm{j}$ & $64.78 \mathrm{hi}$ & $0.43 \mathrm{f}$ & $0.36 \mathrm{e}$ & $44.38 \mathrm{i}$ & $59.03 \mathrm{~h}$ \\
\hline \multirow{3}{*}{$\mathrm{SA}+\mathrm{RS}$} & alone & $1.94 \mathrm{jk}$ & $1.29 \mathrm{j}$ & $78.44 a b c$ & $85.70 \mathrm{c}$ & $0.22 \mathrm{~m}$ & $0.21 \mathrm{kl}$ & $69.28 \mathrm{a}$ & $76.14 \mathrm{bc}$ \\
\hline & PDB & $3.27 \mathrm{~g}$ & $2.98 \mathrm{f}$ & $63.67 \mathrm{f}$ & $66.85 \mathrm{~g}$ & $0.29 \mathrm{k}$ & $0.29 \mathrm{~h}$ & $66.03 \mathrm{~b}$ & $66.22 \mathrm{f}$ \\
\hline & TRE & $2.08 \mathrm{ij}$ & $1.30 \mathrm{j}$ & $76.89 \mathrm{~cd}$ & $85.59 \mathrm{c}$ & $0.23 \mathrm{~m}$ & $0.25 \mathrm{i}$ & $64.35 b c$ & $71.16 \mathrm{e}$ \\
\hline \multirow{3}{*}{$\mathrm{HL}$} & alone & $3.27 \mathrm{~g}$ & $2.28 \mathrm{~g}$ & $63.67 \mathrm{f}$ & $74.67 \mathrm{f}$ & $0.33 j$ & $0.32 \mathrm{f}$ & $56.20 \mathrm{f}$ & $63.38 \mathrm{~g}$ \\
\hline & PDB & $4.95 \mathrm{~b}$ & $1.09 \mathrm{k}$ & $44.96 \mathrm{k}$ & $87.89 \mathrm{~b}$ & $0.35 \mathrm{i}$ & $0.39 \mathrm{~d}$ & $52.71 \mathrm{gh}$ & $54.16 j$ \\
\hline & TRE & $4.26 \mathrm{~d}$ & $3.96 \mathrm{~b}$ & $52.67 \mathrm{i}$ & $55.96 \mathrm{k}$ & $0.38 \mathrm{~h}$ & $0.37 \mathrm{e}$ & $53.18 \mathrm{gh}$ & $57.15 \mathrm{i}$ \\
\hline \multirow{3}{*}{$\mathrm{HL}+\mathrm{RS}$} & alone & 1.781 & 0.961 & $80.19 \mathrm{a}$ & $89.33 a$ & $0.29 \mathrm{k}$ & $0.21 \mathrm{kl}$ & $60.96 \mathrm{de}$ & $75.68 \mathrm{bc}$ \\
\hline & PDB & $2.18 \mathrm{i}$ & $1.68 \mathrm{~h}$ & $75.78 \mathrm{~d}$ & $81.30 \mathrm{e}$ & $0.32 j$ & $0.25 \mathrm{i}$ & $56.24 \mathrm{f}$ & $70.65 \mathrm{e}$ \\
\hline & TRE & $1.88 \mathrm{kl}$ & $1.17 \mathrm{k}$ & $79.07 \mathrm{ab}$ & $87.00 \mathrm{~b}$ & $0.29 \mathrm{k}$ & $0.22 \mathrm{jk}$ & $64.40 \mathrm{bc}$ & $74.83 \mathrm{~cd}$ \\
\hline \multirow{3}{*}{ RS } & alone & $9.00 \mathrm{a}$ & $9.00 \mathrm{a}$ & $0.00 \mathrm{l}$ & $0.00 \mathrm{l}$ & $0.85 b$ & $0.87 \mathrm{a}$ & $0.00 \mathrm{k}$ & $0.00 \mathrm{~m}$ \\
\hline & PDB & $9.00 \mathrm{a}$ & $9.00 \mathrm{a}$ & 0.001 & 0.001 & $0.87 \mathrm{a}$ & $0.88 \mathrm{a}$ & $0.00 \mathrm{k}$ & $0.00 \mathrm{~m}$ \\
\hline & TRE & $9.00 \mathrm{a}$ & $9.00 \mathrm{a}$ & 0.001 & 0.001 & $0.80 \mathrm{c}$ & $0.87 \mathrm{a}$ & $0.00 \mathrm{k}$ & $0.00 \mathrm{~m}$ \\
\hline
\end{tabular}

Values are mean of three independent $(\mathrm{n}=3)$ experiments and means followed by the same letter on superscript within a column are not significantly different $(\mathrm{P} \leq 0.05)$ according to Duncan's Multiple Range Test (DMRT). Rhizoctonia solani $(R S)$, Bacillus amyloliquefaciens MB101 (BA), Streptomyces atrovirens $\mathrm{N} 23$ (SA) and Hypocrea lixii NAIMCC-F-01760 (HL); potato dextrose broth (PDB) and tomato root extract (TRE); alone only water treated.

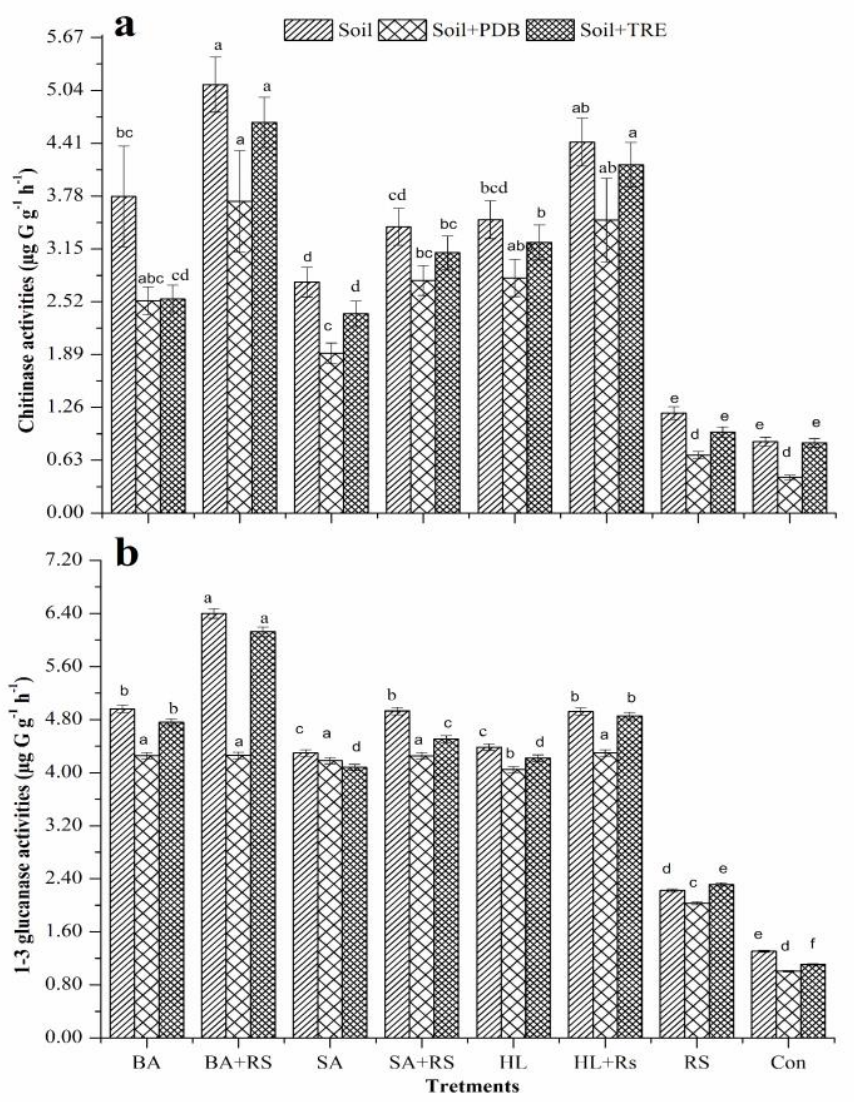

Fig. 2. Effect of nutrient supplements (potato dextrose broth-PDB and tomato root extract-TRE) on production of cell wall degrading enzymes: a - Chitinase and b - $\beta$-1,3 Glucanase; Rhizoctonia solani (RS), Bacillus amyloliquefaciens MB101 (BA), Streptomyces atrovirens N23 $(S A)$ and Hypocrea lixii NAIMCC-F-01760 (HL), the vertical bars indicate the standard error of three replications $(\mathrm{n}=3)$ and different letters on the error bars indicate significant difference $(P \leq 0.05)$ analyzed by Duncan's Multiple Range Test (DMRT) 


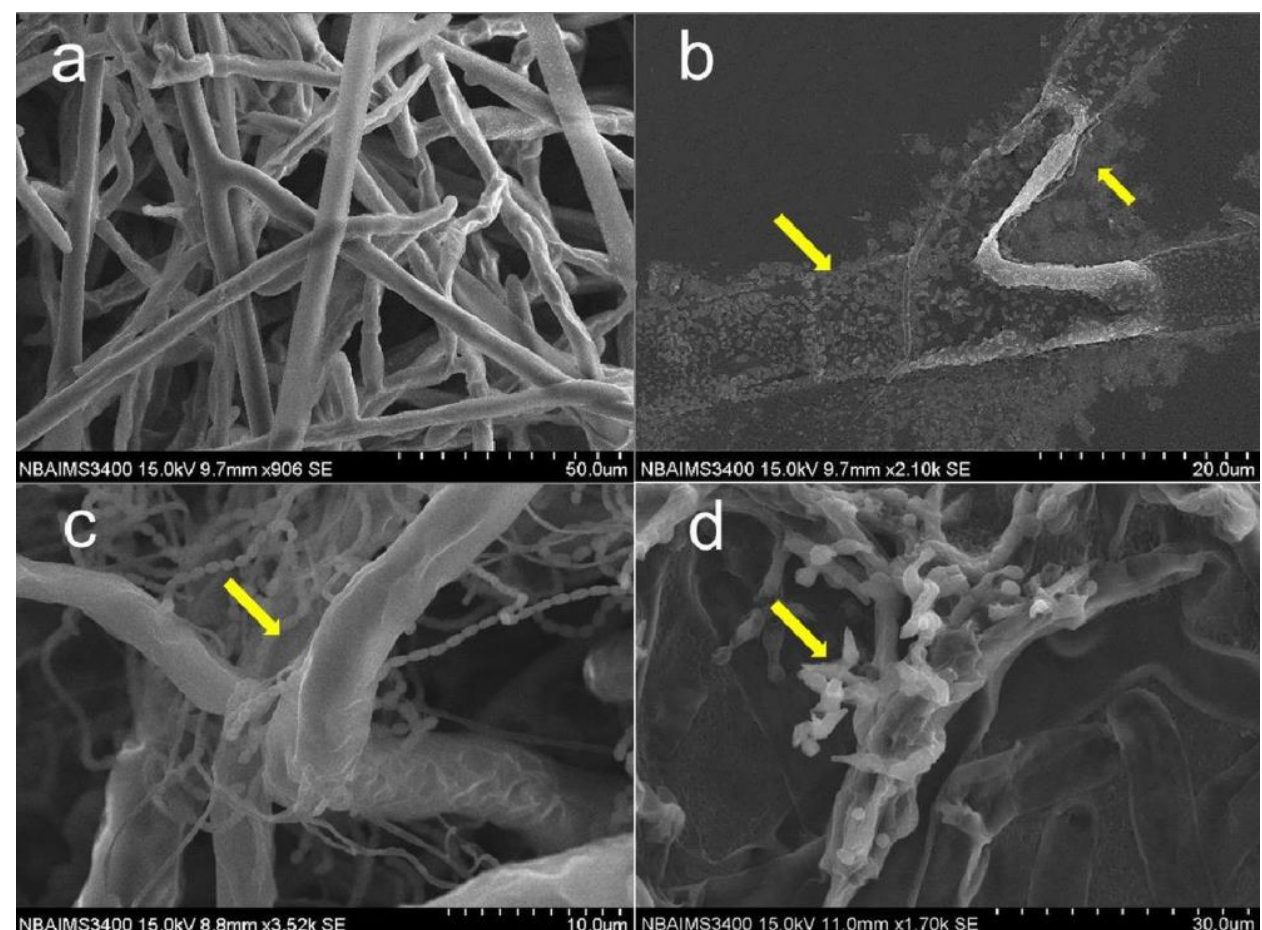

Fig. 3. Scanning electron micrographs of interactions between three antagonistic microbes and Rhizoctonia solani (RS) under a soil microcosm after 21 days: a - RS control adopted from Malviya et al. (2014) for comparison; b - Bacillus amyloliquefaciens MB101 (BA); c - Streptomyces atrovirens N23 (SA); d - Hypocrea lixii NAIMCC-F-01760 (HL), yellow arrows showing the attachment and coiling of antagonism on pathogens

\section{Discussion}

Mostly, plant microbe interaction can be classified as pathogenic, saprophytic and beneficial (Kundan and Pant, 2015; Patil and Solanki, 2016a). Biological control is the one of the most beneficial interaction, where microorganisms manage the plant diseases caused by soil-borne plant pathogens and it has been considered to be a more natural and biologically acceptable alternative to the existing chemical treatment methods (Finkel et al., 2017). Among all microbes, Trichoderma/Hypocrea spp., Bacillus spp. and Streptomycetes spp. have been identified as promising resources for biocontrol of plant diseases (Shoresh et al., 2010; Solanki et al., 2012b, 2016). In the current study, three microbes $(B A, S A$ and $H L)$ were used against a sclerotia producing pathogen $R$. solani. On the basis of invitro confrontation assay results, the experiment was conducted in soil microcosm in controlled conditions to understand the role of nutrient based antagonism. Nutrient competition is the key mechanism and mostly enhanced the parasitism and antibiosis activity of antagonistic microbes (Harman et al., 2004). Concerning the competition for nutrients, in the hereby study an artificial rhizosphere system (soil microcosm) was organized with or without $R$. solani a virulent pathogen of tomato root rot. Artificial substrate (potato dextrose broth-PDB) and natural substrate (tomato root extract-TRE) were used as nutrient supplements in the soil microcosm with three important antagonistic microbes $(B A, S A$ and $H L)$, and after 21 days, soil extracts were collected and antifungal activity and CWDE's quantity were assessed. Results showed nutrient supplementation influence the antifungal activity of soil extract with the presence of $R S$ and antagonistic microbes. Maximum antifungal activity thought growth inhibition resulted with $H L+R S$ and was followed by $B A+R S$ and $S A+R S$ in the presence of $R S$ without supplementation. However, only $B A$ inhibited maximum mycelia growth of $R S$ without substrate as compared to $H L$ and $S A$ and it was followed by the natural substrate (TRE). Different antifungal activity against $R S$, in the antagonist treated microcosm give an idea that CWDEs may play a critical role in the inhibition of $R S$.

Moreover, several reports also proved that chitinases and $\beta$-1, 3-glucanases have been playing a significant role in the mycoparasitic interaction of Trichoderma species against the different fungal pathogen (Almeida et al., 2007; Solanki et al., 2011). Because the major component of the cell wall of plant pathogen is made up by chitin and glucans (Gao et al., 2005; Cao et al., 2009). Therefore, the quantification of CWDEs with or without pathogen becomes essential for the present study. Thus, in the presence of $R S$, maximum chitinase accumulation accrued with $B A+R S$ without supplementation and similar trends also followed by $H L+R S$. Similarly, $\beta$-1, 3-glucanase also resulted maximum with $B A+R S$ in the absence of PDB and TRE and was followed by $R S+T R E$. In the presence of $R S$, all microbes produced significant amounts of chitinases and $\beta-1,3$ glucanases and it is to be reduced when supplements were added, respectively. After antifungal activity and quantification of CWDE's, antagonist interaction accessed via SEM, and significant damaged mycelia of $R S$ recovered with all antagonists treated microcosm without supplementation. 
398

\section{Conclusions}

In conclusion, the present investigation stated that nutrient supplementation negatively affect the antagonism and the results had great significance in the mycoparasitism study. The present findings support the nutrient competition mechanism and prove that the presence of substrate can reduce the mycoparasitism and antibiosis of microbes; a natural substrate like tomato root extract is also the best choice to understand the biocontrol mechanism as compared to the artificial substrates. Soil microcosm technique can be used to characterize different kinds of antagonistic microbes in the future and it is quite similar like soil system. Moreover, chains of experiments are needed to understand the nutrient competition in the presence of physiological factor and abiotic stress conditions and it is our future mandate to explore all possible factors and their regulatory effect on the antagonism.

\section{Acknowledgements}

The present work was funded by the Indian Council of Agriculture Research (ICAR) by a network project 'Application of Microorganisms in Agriculture and Allied Sectors' (AMAAS).

\section{References}

Almeida FB dos R, Cerqueira FM, Silva R do N, et al, Lima AL (2007). Mycoparasitism studies of Trichoderma harzianum strains against Rhizoctonia solani: evaluation of coiling and hydrolytic enzyme production. Biotechnology Letters 29(8):118993.

Arora NK, Khare E, Oh JH, Kang SC, Maheshwari DK (2008). Diverse mechanisms adopted by fluorescent Pseudomonas PGC2 during the inhibition of Rhizoctonia solani and Phytophthora capsici. World Journal of Microbiology and Biotechnology 24(4):581-585.

Bais HP, Weir TL, Perry LG, Gilroy S, Vivanco MJ (2006). The role of root exudates in rhizosphere Interactions with plants and other organisms. Annual Reviews in Plant Biology 57:233-266.

Boukaew S, Chuenchit S, Petcharat V (2011). Evaluation of Streptomyces spp. for biological control of Sclerotium root and stem rot and Ralstonia wilt of chili pepper. BioControl 56:365-374.

Cao R, Liu X, Gao K, Mendgen K, Kang Z, Gao J, et al, Wang X(2009). Mycoparasitism of endophytic fungi isolated from reed on soilborne phytopathogenic fungi and production of cell wall-degrading enzymes in vitro. Current Microbiology 59(6):584-592.

Compant S, Clément C, Sessitsch A (2010). Plant growth-promoting bacteria in the rhizo- and endosphere of plants: Their role, colonization, mechanisms involved and prospects for utilization. Soil Biology and Biochemistry 42(5):669-678

Doornbos RF, van Loon LC, Bakker PAHM (2012). Impact of root exudates and plant defense signaling on bacterial communities in the rhizosphere. A review. Agronomy for Sustainable Development 32(1):227-243.

Finkel OM, Castrillo G, Herrera Paredes S, et al., Dangl KL (2017). Understanding and exploiting plant beneficial microbes. Current
Opinion in Plant Biology 38:155-163.

Gao K, Liu X, KangZ, Mendgen K (2005). Mycoparasitism of Rhizoctonia solani by endophytic chaetomium spirale ND35: Ultrastructure and cytochemistry of the interaction. Journal of Phytopathology 153:280290.

Harman G, Howell C, Viterbo A (2004). Trichoderma speciesopportunistic, avirulent plant symbionts. Nature Reviews Microbiology 2(1):43-56.

Hartmann A, Schmid M, Tuinen D van, Berg G (2009). Plant-driven selection of microbes. Plant Soil 321:235-257.

Huang Y, Kuang Z, Wang W, Cao L (2016). Exploring potential bacterial and fungal biocontrol agents transmitted from seeds to sprouts of wheat. Biological Control 98:27-33.

Kundan R, Pant G (2015). Plant growth promoting Rhizobacteria: Mechanism and current prospective. Journal of Fertilizers and Pesticides 6(2):9.

Lethbridge G, Bull AT, Burns RG (1978). Assay and properties of 1,3- $\beta$ glucanase in soil Soil Biolog and Biochemistry 10(5):389-391.

Luo D-Q, Wang F, Bian X-Y, Liu J-K (2005). Rufuslactone, a new antifungal sesquiterpene from the fruiting bodies of the basidiomycete Lactarius rufus. The Journal of Antibiotics 58(7):456459.

Malviya N, Yandigeri MS, Yadav AK, Solanki MK, Arora DK (2014). Isolation and characterization of novel alkalithalophilic actinomycetes from the Chilika brackish water lake, India. Annals of Microbiology 64(4):1829-1838.

Morton DJ, Stroube WH (1955). Antagonistic and stimulating effects of soil microorganisms upon Sclerotium rolfsii. Phytopathology 45:417420.

Patil HJ, Solanki MK (2016a). Microbial inoculant: Modern era of fertilizers and pesticides. Microbial Inoculants in Sustainable Agricultural Productivity 319-343.

Patil HJ, Solanki MK (2016b). Molecular prospecting: Advancement in diagnosis and control of Rhizoctonia solani diseases in plants. Springer International Publishingpp 165-185.

Shoresh M, Harman G, Mastouri F (2010). Induced systemic resistance and plant responses to fungal biocontrol agents. Annual Review of Phytopathology 48:21-43.

Solanki MK, Kumar S, Pandey AK, et al., Arora DK (2012a). Diversity and antagonistic potential of Bacillus spp. associated to the rhizosphere of tomato for the management of Rhizoctonia solani. Biocontrol Science and Technology 22(2):203-217.

Solanki MK, Malviya MK, Wang Z (2016). Actinomycetes bio-inoculants: A modern prospectus for plant disease management. In Plant Growth PromotingActinobacteria36-81.

Solanki MK, Robert AS, Singh RK, et al, Arora DK (2012b). Characterization of mycolytic enzymes of Bacillus strains and their bioprotection role against Rhizoctonia solani in tomato. Current Microbiology65(3):330-336.

Solanki MK, Singh N, Singh RK, et al., Arora DK (2011). Plant defense activation and management of tomato root rot by a chitin-fortified Trichoderma/Hypocrea formulation. Phytoparasitica 39(5):471-481.

Solanki MK, Singh RK, Srivastava S, et al., Arora DK (2014a). Isolation and characterization of siderophore producing antagonistic rhizobacteria 
againstRhizoctonia solani.Journal of Basic Microbiology 54(6):585-597.

Solanki MK, Singh RK, Srivastava S, et al, Arora DK (2014b). Isolation and characterization of siderophore producing antagonistic rhizobacteria againstRhizoctonia solani.Journal of Basic Microbiology 54(6):585-597.

Trotta A, Varese GC, Gnavi E, Fusconi A, Sampo S, Berta G (1996). Interactions between the soilbome root pathogenPhytophthora nicotianae varparasitica and the arbuscular mycorrhizal fungus Glomus mosseae in tomato plants. Plant Soil 185(2):199-209.

Wen C-M, Tseng C-S, Cheng C-Y, Li Y-K (2002). Purification, characterization and cloning of a chitinase from Bacillus sp. NCTU2. Biotechnology and Applied Biochemistry 35(3):213-219.
Yandigeri MS, Malviya N, Solanki MK, Shrivastav P, Sivakumar G (2015). Chitinolytic Streptomyces vinaceusdrappus S5MW2 isolated from Chilika lake, India enhances plant growth and biocontrol efficacy through chitin supplementation against Rhizoctonia solani. World Journal of Microbiology and Biotechnology 31(8):1217:1225.

Yu G, SinclairJ, Hartman G, Bertagnolli B (2002).Production of iturin A by Bacillus amyloliquefaciens suppressing Rhizoctonia solani. Soil Biology and Biochemistry34:955-963. 